\title{
13. CRETACEOUS OSTRACODES OF IPOD LEG 48 (HOLES 400, 400A, 401, AND 402A)
}

Renée Damotte, Centre National de la Recherche Scientifique, Université Pierre et Marie Curie, Paris, France

Examination of Cretaceous ostracodes of IPOD Leg 48 revealed a meager fauna of small sized individuals. There were no representatives of genera such as Cythereis, Protocythere, Platycythereis, Bairdia, and Cytherelloidea, which are characteristic and abundant in the neretic Cretaceous deposits of Europe. Eight species were found.

Site 400: Core 71 contains only one valve of Cytherella $\mathrm{gr}$. ovata, which occurs throughout the Cretaceous.

Hole 400A: In Core 68, a single valve of Asciocythere was found; the age cannot be indicated. Core 69 contains small Paranotacythere? sp. 69, which genus occurs in the European Lower Cretaceous. Foraminifers in this core indicate an Aptian age; our species' likeness with the Aptian species Paranotacythere luettigi would confirm this.

Site 401: In Core 18, Cytherella gr. ovata and Bythoceratina sp. 18 are present, suggesting an Upper Cretaceous (Senonian-Maestrichtian) association. Bythoceratina sp. 18 resembles $B$. umbonatoides Kaye, an indication for a late Senonian or Maestrichtian age.

Site 402: Core 27 contains only Cytherella gr. parallela, which does not permit a precise stratigraphic range within the Cretaceous. In Core 34, two small species were found, Paijenborchellina? sp. 1 Swain and Raymoorea? sp. cf. $R$. peculiaris (Donze) sensu Swain, 1976. According to Swain (1976), this association occurred in Early Cretaceous (Aptian to early Cenomanian) time but he could not determine its precise stratigraphic range.

\section{ECOLOGICAL INTERPRETATIONS}

In Core 71, Site 400, Core 68, Hole 400A, and Core 27, Hole $402 \mathrm{~A}$, specimen size is normal, suggesting conditions to have been normal for the species. At Site 401, the association of Cytherella-Bythoceratina indicates a deep-sea deposit, bathyal or perhaps abyssal. All of these samples are deep-sea deposits, as is confirmed by the absence of Trachyleberidinae, a neritic group, throughout the core. However, the fauna in Core 69, Hole 400A, and in Core 31, Hole 402A, are much smaller than elsewhere known. The dwarfism may be due to unfavorable conditions such as inadequate food supply, and/or cold water, strong currents, etc. Paranotacythere sp. 69 specimens (in Core 69, Hole $400 \mathrm{~A}$ ) possess eye tubercles, which are typical in sunlit water species; these specimens therefore have been washed in from the continental slope.

Because the ostracode valves all are very delicate, a rather calm environment, without strong currents, is suggested.

\section{SYSTEMATICS}

OSTRACODA Latreille, 1806

PLATYCOPA Sars, 1866

\author{
Family CYTHERELLIDAE Sars, 1866 \\ Genus CYTHERELLA Jones, 1949
}

Cytherella gr. ovata (Roemer, 1840)

(Plate 1, Figure 1)

Size: $0.70-0.78 \mathrm{~mm}$, normal size for the species.

Level: Site 400, Core 71, CC, and Site 401, Core 18, CC.

Stratigraphic range: Cytherella ovata appears throughout the Cretaceous (especially Aptian to Maestrichtain).

\section{Cytherella gr. parallela (Reuss, 1845) \\ (Plate 1, Figure 2)}

Size: $0.56 \mathrm{~mm}$; the normal size for this species is $0.60-0.70 \mathrm{~mm}$, but perhaps the specimen found here is a larval stage.

Level: Hole 402A, Core 27, CC.

Stratigraphic range: Throughout the Cretaceous, but especially Aptian to Maestrichtian.

\section{PODOCOPA Sars, 1866}

Family CYTHERIDAE Baird, 1850

Subfamily BYTHOCYTHERINAE Sars, 1926

Genus BYTHOCERATINA Hornibrook, 1952

Bythoceratina sp. 18

Size: $0.75-0.76 \mathrm{~mm}$.

Level: Site 401, Core 18, CC.

Remarks: This species resembles Bythoceratina umbonatoides (Kaye), described by Kaye (1964) from the English Senonian; the Lower Cretaceous forms belong to Bythoceratina umbonata (Williamson). The general shell form of Bythoceratina sp. 18 is like those of Bythoceratina umbonata (Williamson), figured by Herrig (1966) from the Maestrichtian of Rügen Island (Germany), but $B$. umbonata sensu Herrig should be $B$. umbonatoides sensu Kaye.

Stratigraphic range: In Europe, the genus Bythoceratina is found principally in the Upper Cretaceous (Senonian-Maestrichtian).

\section{Subfamily CYTHERIDEINAE Sars, 1866}

Genus ASCIOCYTHERE Swain, 1952

\section{Asciocythere sp. 68 \\ (Plate 1, Figure 5)}

Size: $0.76 \mathrm{~mm}$; size rather large for the genus.

Level: Hole 400A, Core 68, Section 1, $72-73 \mathrm{~cm}$.

Remarks: Only one specimen was found and no further specific identification can be made.

Stratigraphic range: In Europe, this genus appears throughout the Cretaceous.

Subfamily CYTHERURINAE Mueller, 1894

Genus PARANOTACYTHERE Bassiouni, 1974

Paranotacythere sp. 69

(Plate 1, Figures 6, 7) 
Size: $0.27-0.35 \mathrm{~mm}$. This size is very small; most Paranotacythere species measure $0.5-0.8 \mathrm{~mm}$.

Level: Hole 400A, Core 69, Section 1, 128-135 cm.

Remarks: This species differs from all European Paranotacythere species; it is most like Paranotacythere luettigi described by Bassiouni (1974) from the German and English upper Aptian, but the sizes are different: $B$. luettigi's size is $0.55-0.59 \mathrm{~mm}$. The reticulate ornamentation is more important and visible, and the ventral ridge is also more important on Paranotacythere sp. 69 than on $P$. luettigi. The internal shell structures are not readily observable, so some doubt on generic identifications exists.

Stratigraphic range: According to Bassiouni, in Europe the genus Paranotacythere occurs only in Lower Cretaceous rocks.

\section{Genus PAIJENBORCHELLINA Kuznetsova, 1957}

Paijenborchellina? sp. 1 Swain, 1976

(Plate 1, Figure 8)

Size: $0.27 \mathrm{~mm}$; the size of Swain's species is the same.

Level: Hole 402A, Core 34, CC.

Remarks: Because in Swain's species, the internal shell structures have not been observed, further identification is not possible.

Stratigraphic range: Swain suggested an age of late Aptian to early Cenomanian.

\section{Subfamily PROGONOCYTHERINAE Sylvester Bradley, 1948}

Genus RAYMOOREA Neale, 1967

Raymoorea? sp. cf. R. peculiaris (Donze, 1965) sensu Swain, 1976 (Plate 1, Figure 9)

Size: $0.20 \mathrm{~mm}$, but the posterior part is broken. The size of Swain's species is $0.20-0.22 \mathrm{~mm}$.

Level: Hole 402A, Core 34, CC.

Remarks: Specific identification is rather difficult because the specimen is corroded and the posterior part broken. The general outline is like that of Swain's species, but, in my opinion, the identification of Swain's species as $R$. peculiaris (Donze) needs confirmation.

Stratigraphic range: $R$. peculiaris sensu Swain occurred in Early Cretaceous time (Aptian to early Cenomanian) but this is not confirmed.
Family CYPRIDIDAE Baird, 1850

\section{Subfamily PARACYPRIDINAE Sars, 1923}

Genus PARACYPRIS Sars, 1866

\section{Paracypris cf. acuta (Cornuel, 1848)}

(Plate 1, Figure 10)

Size: $0.37-0.52 \mathrm{~mm}$. This size is small for the species; the normal size (in the Paris Basin) being $0.57-0.75 \mathrm{~mm}$.

Level: Hole $402 \mathrm{~A}$, Core 34 , Section $62,34-38 \mathrm{~cm}$.

Remarks: The general shell form is quite like those of $P$. acuta found in the Lower Cretaceous of the Paris Basin.

Stratigraphic range: In northern Europe, Paracypris acuta also appears in the Lower Cretaceous (Hauterivian to Aptian).

\section{ACKNOWLEDGMENTS}

M. Montadert (Institut Français du Pétrole) collected the material for the writer and has critically read this paper; the writer thanks him and Dr. Peypouquet (University of Bordeaux) for their valuable advice.

\section{REFERENCES}

Bassiouni, M.E.A., 1974. Paranotacythere n. g. (Ostracoda) aus dem Zietraum Oberjura bis Unterkreide (Kimmeridgium bis Albium) von Westeuropa, Geol. Jarhberg, no. 17, p. 3-111.

Herrig, E., 1966. Ostracoden aus der Weissen Schreibkreide (Unter Maastricht) der Insel Rügen, Paläontol. Abhand., Abt. A, II, v. 4, p. 693-1024.

Kaye, P., 1964. Revision of British marine Cretaceous Ostracoda with notes on additional forms, British Mus. Nat. Hist. Bull., v. 10 , p. 37-79.

Neale, J.W., 1967. Ostracodes from the type Berriasian (Cretaceous) of Berrias (Ardiche, France) and their significance. Essays in paleontology and stratigraphy, University of Kansas, Spec. Publ., no. 2, p. 539-569.

Swain, F.M., 1976. Lower and Middle? Cretaceous Ostracoda from the Atlantic Ocean off Guiana and off West Africa, $J$. Paleontol., v. 50, p. 734-753. 


\section{PLATE 1}

Figure $1 \quad$ Cytherella gr. ovata (Roemer). Site 400, Core 71, CC. Carapace, right side view. $\times 105$.

Figure 2 Cytherella gr.parallela (Reuss). Hole 402A, Core 27, CC. Left valve. $\times 120$.

Figures 3, $4 \quad$ Bythoceratina sp. 18 Site 401, Core 18, CC.

3. Left valve. $\times 90$.

4 , Right valve. $\times 105$.

Figure $5 \quad$ Asciocythere sp. 68. Hole 400A, Core 68, Section 1, $72-73 \mathrm{~cm}$. Right valve, internal view. $\times 90$.

Figures 6, 7 Paranotacythere sp. 69. Hole 400A, Core 69, Section $1,128-135 \mathrm{~cm}$.

6. Right valve. $\times 210$.

7. Left valve. $\times 260$.

Figure $8 \quad$ Paijenborchellina sp. 1 Swain. Hole 402A, Core 34, CC. Left valve. $\times 300$.

Figure $9 \quad$ Raymoorea? sp. cf. $R$. peculiaris (Donze) sensu Swain. Hole 400A, Core 34, CC. Broken left valve. $\times 375$.

Figure 10 Paracypris cf. acuta (Cornuel). Site 402, Core 34, Section $62,34-38 \mathrm{~cm}$. Carapace, left-side view. $\times 185$. 
PLATE 1
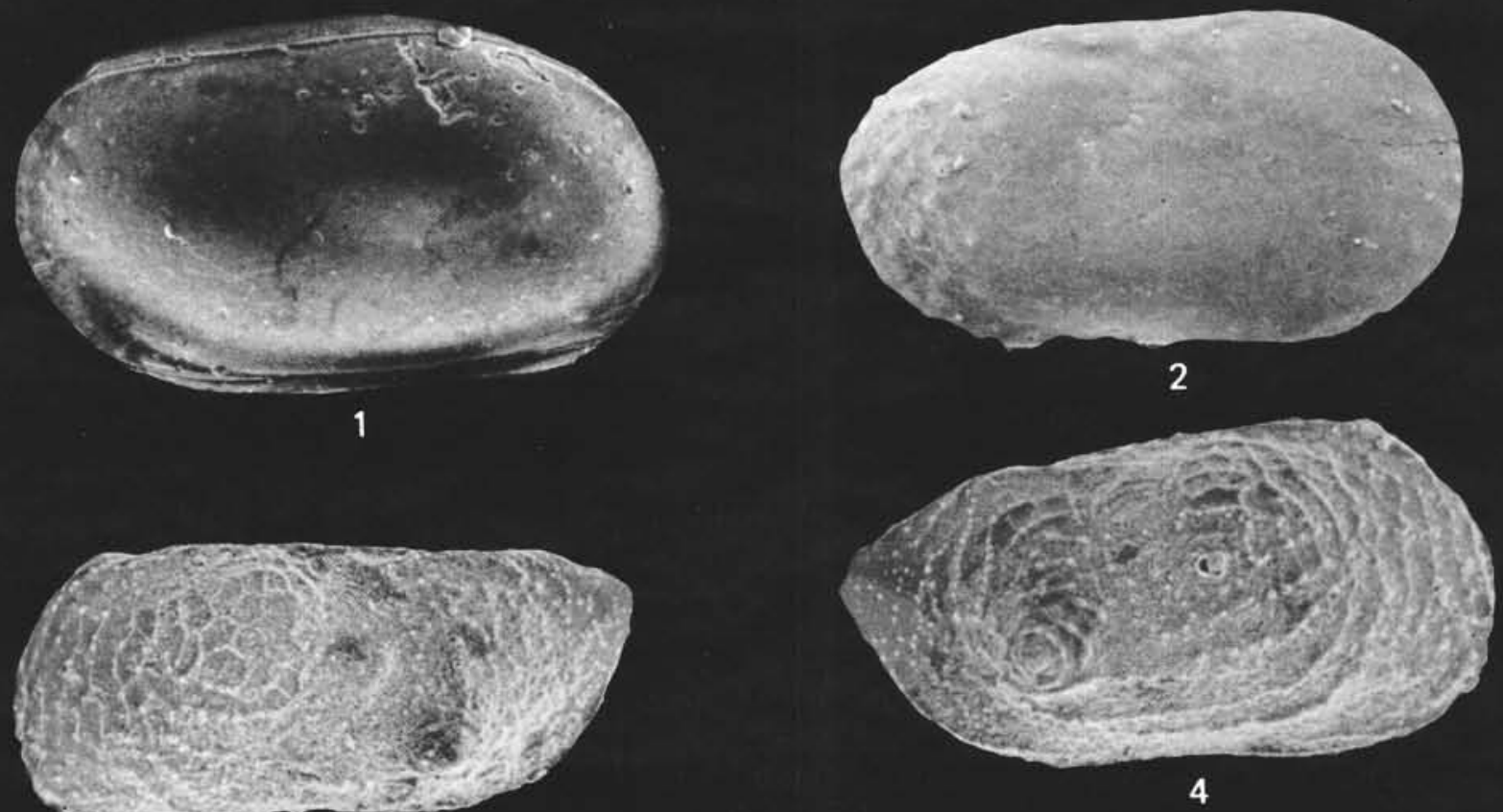

\section{3}
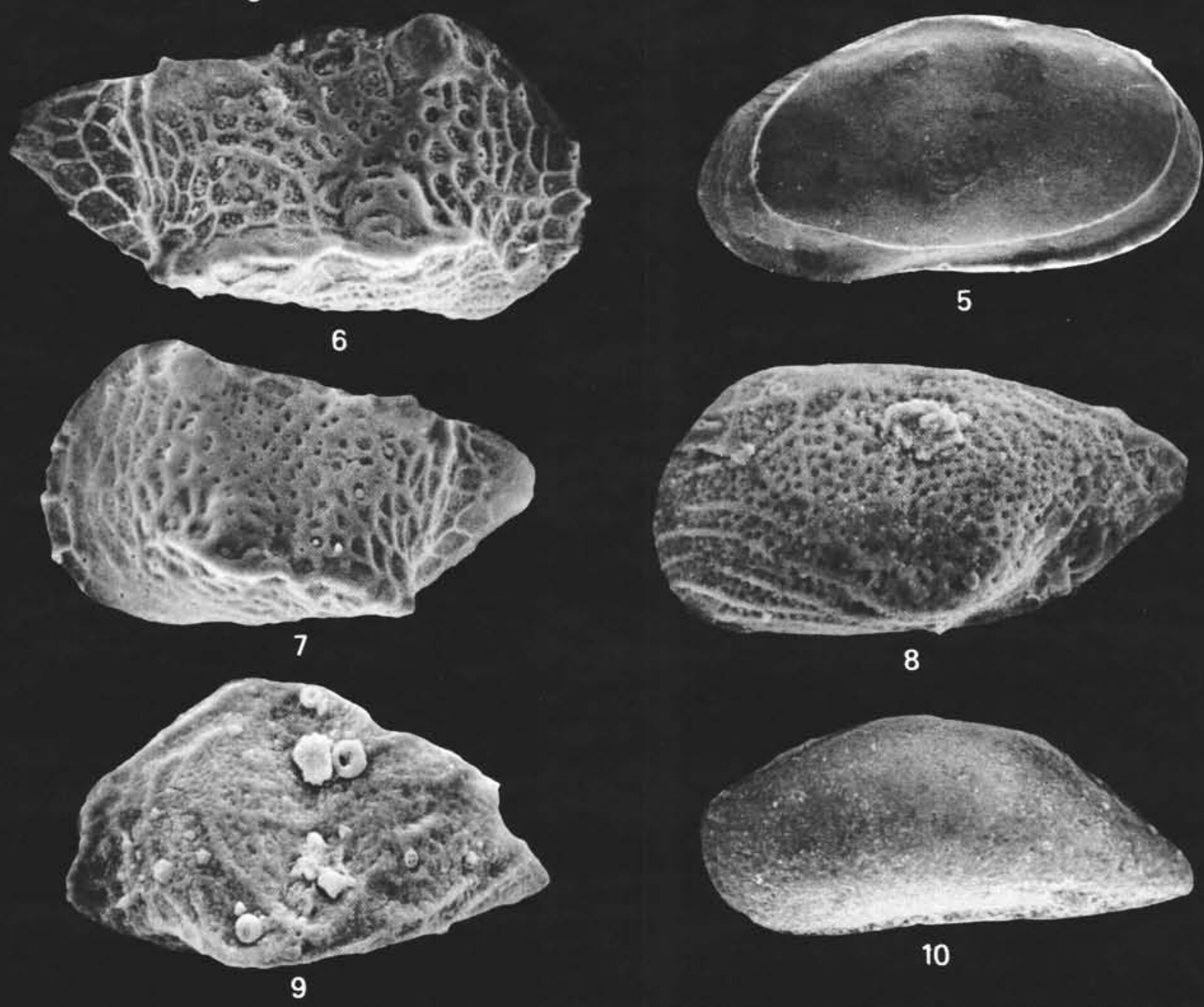